\title{
Subsurface Structural Mapping Using Combined Terrestrial and Grace Gravity Data of the Adamawa Plateau (North-Cameroon)
}

\author{
Bouba Apollinaire ${ }^{1,2^{*}}$, Kamguia Joseph ${ }^{2,3}$, Tabod Charles Tabod ${ }^{2}$, Yap Loudi' ${ }^{2}$, Nouayou Robert ${ }^{2}$, \\ Kande Houetchak Ludovic ${ }^{3}$, Oyoa Valentin ${ }^{1}$
}

${ }^{1}$ Department of Physics, Higher Teachers' Training College, University of Maroua, Maroua, Cameroon

${ }^{2}$ Department of Physics, Faculty of Science, University of Yaounde I, Yaounde, Cameroon

${ }^{3}$ National Institute of Cartography, Yaounde, Cameroon

Email: *boubaapollinaire@yahoo.fr

How to cite this paper: Apollinaire, B., Joseph, K., Tabod, T.C., Loudi, Y., Robert, N., Ludovic, K.H. and Valentin, O. (2017) Subsurface Structural Mapping Using Combined Terrestrial and Grace Gravity Data of the Adamawa Plateau (North-Cameroon). International Journal of Geosciences, 8, 869-887.

https://doi.org/10.4236/ijg.2017.87050

Received: May 27, 2017

Accepted: July 14, 2017

Published: July 17, 2017

Copyright $\odot 2017$ by authors and Scientific Research Publishing Inc. This work is licensed under the Creative Commons Attribution International License (CC BY 4.0).

http://creativecommons.org/licenses/by/4.0/

\begin{abstract}
In order to analyze and determine the geological structures of the Adamawa plateau, the terrestrial gravity data were combined to data computed from GGM02C gravity model. The dense gravity net obtained were further introduced into qualitative and quantitative interpretations. The resulting Bouguer anomaly map obtained from combined data shows NE-SW direction which nearly coincides with the main direction of the fractures affecting the basement in the region and indicates strong gradients marking the presence of discontinuities between heavy and negative gravity anomaly. In order to conduct the quantitative interpretation of the combined gravity data, three profiles were drawn on the residual Bouguer anomaly map and therefore were interpreted using spectral analysis method and 3D density inversion. The knowledge of the depth and density of the geological structures show an uplift of dense rocks under the granite-gneiss substratum. This dense material found in the ENE-WSW direction of the Adamawa Plateau is interpreted as basaltic intrusion probably resulting from tectonic processes. According to this study, the depths of $3.83 \mathrm{~km}$ and $9.62 \mathrm{~km}$ are the new values of depths obtained for futures investigations in the Adamawa plateau.
\end{abstract}

\section{Keywords}

GGM02C, Adamawa Plateau, Bouguer Anomaly, 3D Density Model, Spectral Analysis

\section{Introduction}

The study area lies over the Adamawa Plateau (northern Cameroon) between 
latitudes $5^{\circ}$ and $8^{\circ} \mathrm{N}$, and longitudes $13^{\circ}$ to $15^{\circ} \mathrm{E}$. Previous geophysical and geological studies have been conducted in this area. These include the works of [1] [2] [3] [4] [5]. Some of the above mentioned studies are based on the geophysical signatures of geological units deduced from gravity analyses and their quantitative interpretation. However, a closer look to the terrestrial gravity net of the study area shows that there are many gaps. This might lead to many approximations in geophysical gravity anomaly analyses and interpretations in the region. Hence, the analyses and interpretations should be based on maps showing the real signatures of the geological features. To achieve this goal, a dense gravity net is needed. New gravity campaigns are indicated to fill the gaps. A global geopotential model can also be a solution. Merry [6] showed that GRACE models are more representative of geoid undulations and gravity anomalies in Africa. From statistical studies, [7] [8] showed that gravity data from GGM02C and terrestrial ones have the same precision. In this work, GGM02C gravity data combined to terrestrial ones will be exploited to reinforce the precision of the previous works.

The main objective in this work is to interpret a new Bouguer anomaly map obtained from combined terrestrial and GRACE gravity model GGM02C, then determine the depth and density of the geological structure associated with the crustal formation from a dense gravity net in the study area. On residual Bouguer anomaly map, spectral analysis technic and 3D density inversion were obtained. This method has already been successfully used by [9] [10] to determine the major subsurface structure in the northern edge of the Congo-Craton. With these approaches, we complete the previous geophysical works which used only the terrestrial gravity data.

\section{Geological Setting}

Previous geological and geophysical studies conducted in the Adamawa plateau (Figure 1) indicated that this area is predominantly composed by Precambrian rocks such as migmatic, gneisses and granites that were granitized during the Pan-African tectonic event [12] [13]. It is covered by a sequence of tertiary basaltic lavas [14] (Figure 2). These lavas are alkaline, indicating affinity with continental rifts [15]. Sedimentary formations consist mainly of conglomerates, arkosic sandstone and limestone from the Cretaceous Djerem basin and Mbere ditch [14]. These formations have undergone intense volcanic activity leading to the establishment of the basin structure, covered by volcanic materials which reach the surface through deep fractures. These fractures have a location at the base of major crustal lineaments [16]. Three major tectonic structures are associated with the Adamawa Plateau: the Cameroon Volcanic Line (CVL), the Foumban Shear Zone (FSZ) and the South Adamawa Trough (SAT). The CVL is a chain of intra-plate volcano shaped $Y$ which extends from the island of Pagalu in the Atlantic Ocean west of Africa until about $2000 \mathrm{~km}$ [17]. The first branch (north) corresponds to the Benue through and the second branch (east) the Adamawa plateau. Volcanic rocks on this line are composed of alkali basalt, trachyte 


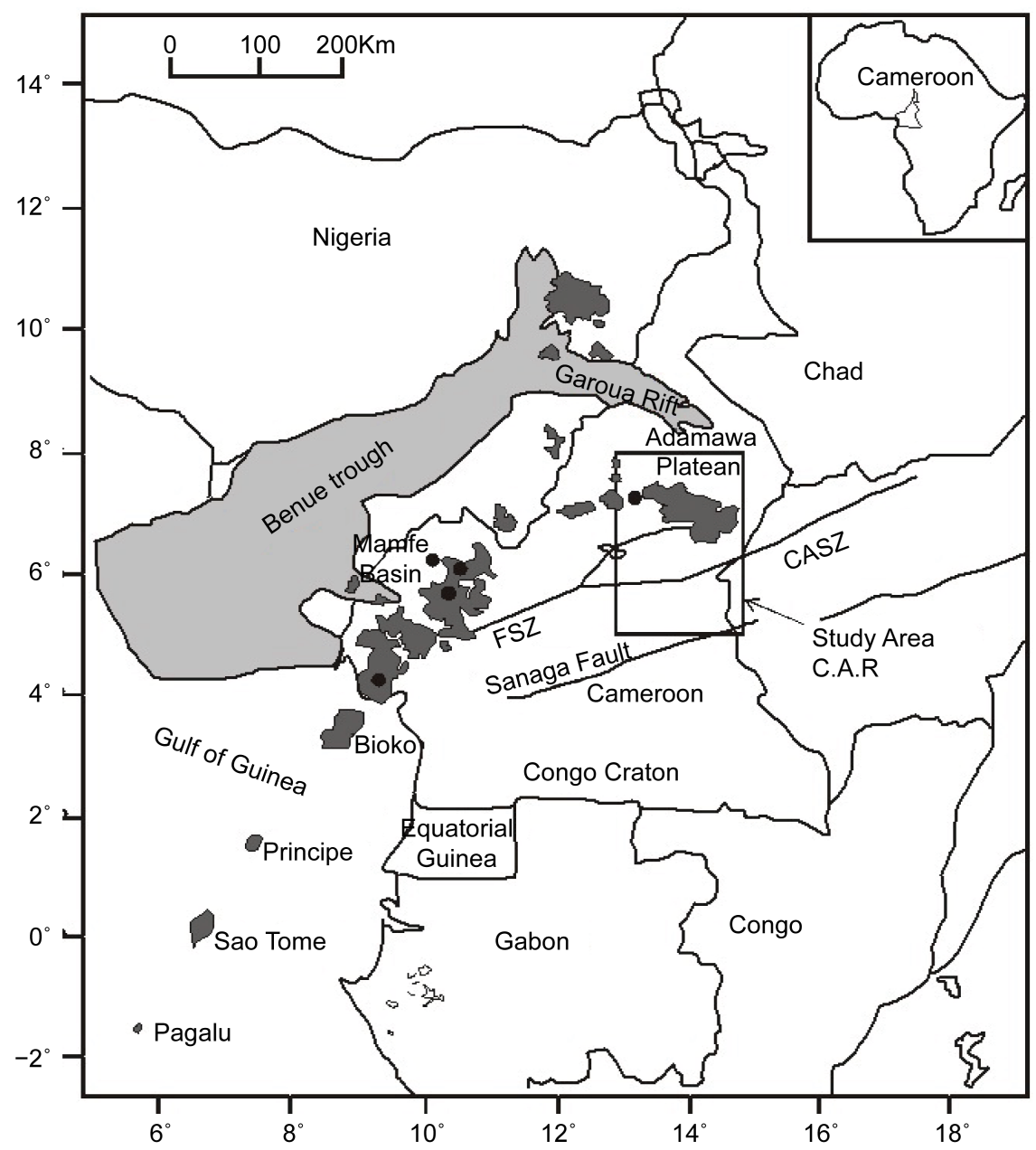

Figure 1. Location map of the Adamawa region-Cameroon modified after [11].

lavas and tuffs. The Foumban Shear Zone is a succession of major accident covered by a series of tertiary volcanoes that one follows from Sudan, through the Central African Republic and Chad up to Foumban in Cameroon [18]. To the west, it is an extension of the pernambuco fault in the north-east of Brazil [19]. The FSZ in Cameroon center displays a dextral sense of displacement [13] [18]. The South Adamawa Trough includes the Cretaceous Mbere ditch and Djerem basin. It is a deep scarps bounded by two faults up to $600 \mathrm{~m}$ high command [14]. This gap is due to the movement of the south Atlantic to the Upper Cretaceous [16] [20].

\section{Gravity Data and Methods}

In this study terrestrial gravity data and data from the global geopotential model GGM02C are available.

\subsection{Terrestrial Gravity Data}

In this study, terrestrial gravity data were obtained by the "Office de la Recherche Scientifique et Technique d'Outre-Mer" (ORSTOM) [12] [21]. This 


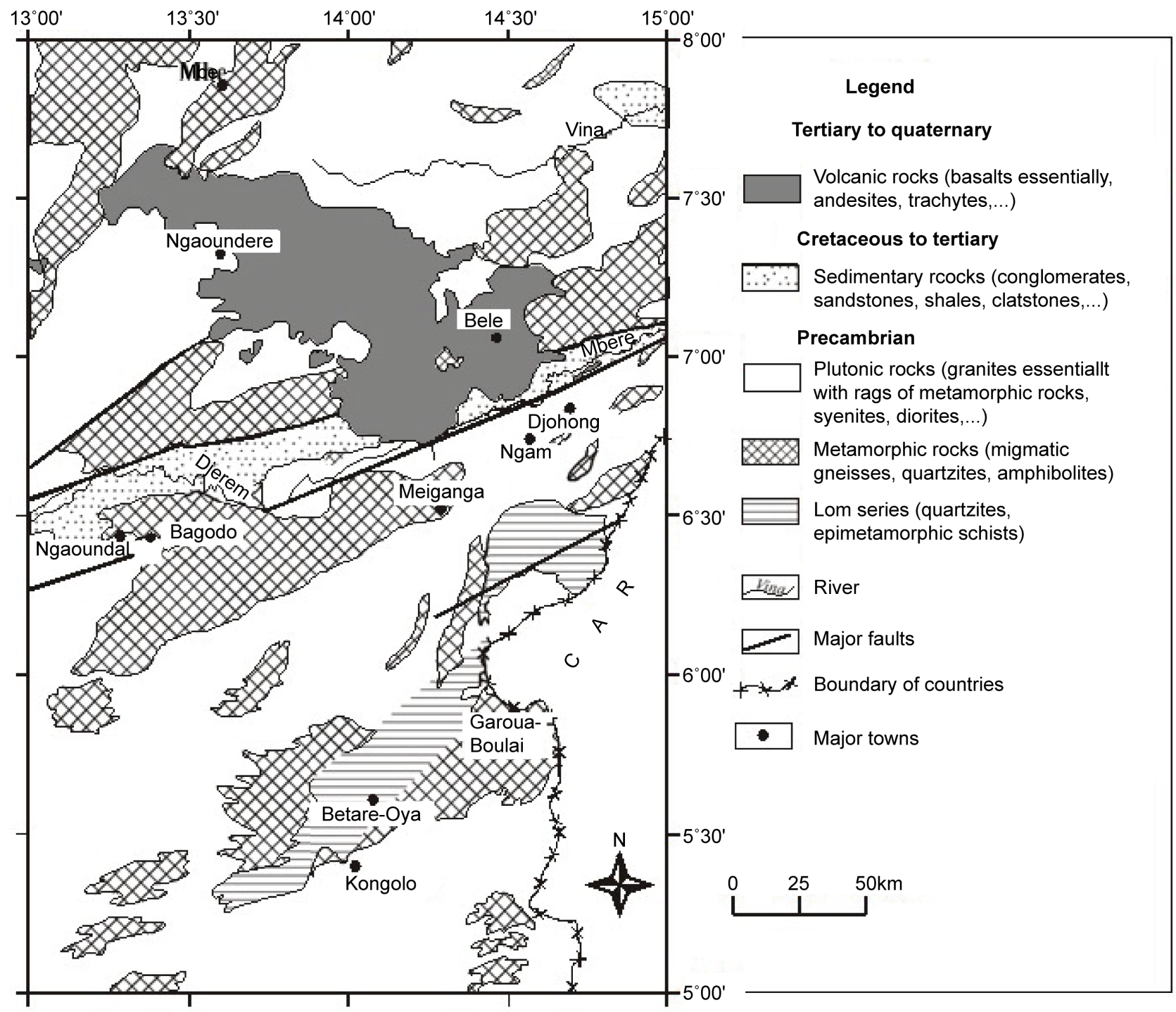

Figure 2. Geological map of the Adamawa region-Cameroon modified from [14].

organization has a very large database and excellent quality recognized internationally. These data were acquired with the Worden and Lacoste Romberg gravimeters. All gravity measurements are tied to the International Gravity Standardization Network 1971 (IGSN71) datum after correction of luni-solar effect and instrumental drift. To determine the free air anomaly, the linear vertical gradient of $0.3086 \mathrm{mGal} / \mathrm{m}$ was used to approximate free air correction. Coordinates stations were determined from topographic maps. Elevation values were obtained with Wallace and Tiernan altimeters. An average rock density of 2.67 $\mathrm{g} / \mathrm{m}^{3}$ was introduced for simple Bouguer reduction. Due to the presence of relatively smooth topography, no terrain correction was added. The resulting Bouguer anomaly contour map in the study area Figure 3 constructed using the Generic Mapping Tools (GMT) [22] shows three gravity sectors.

The first sector, located in the central part of the study area consists of a vast negative anomaly that goes from Garoua-Boulai to Djohong passing through 


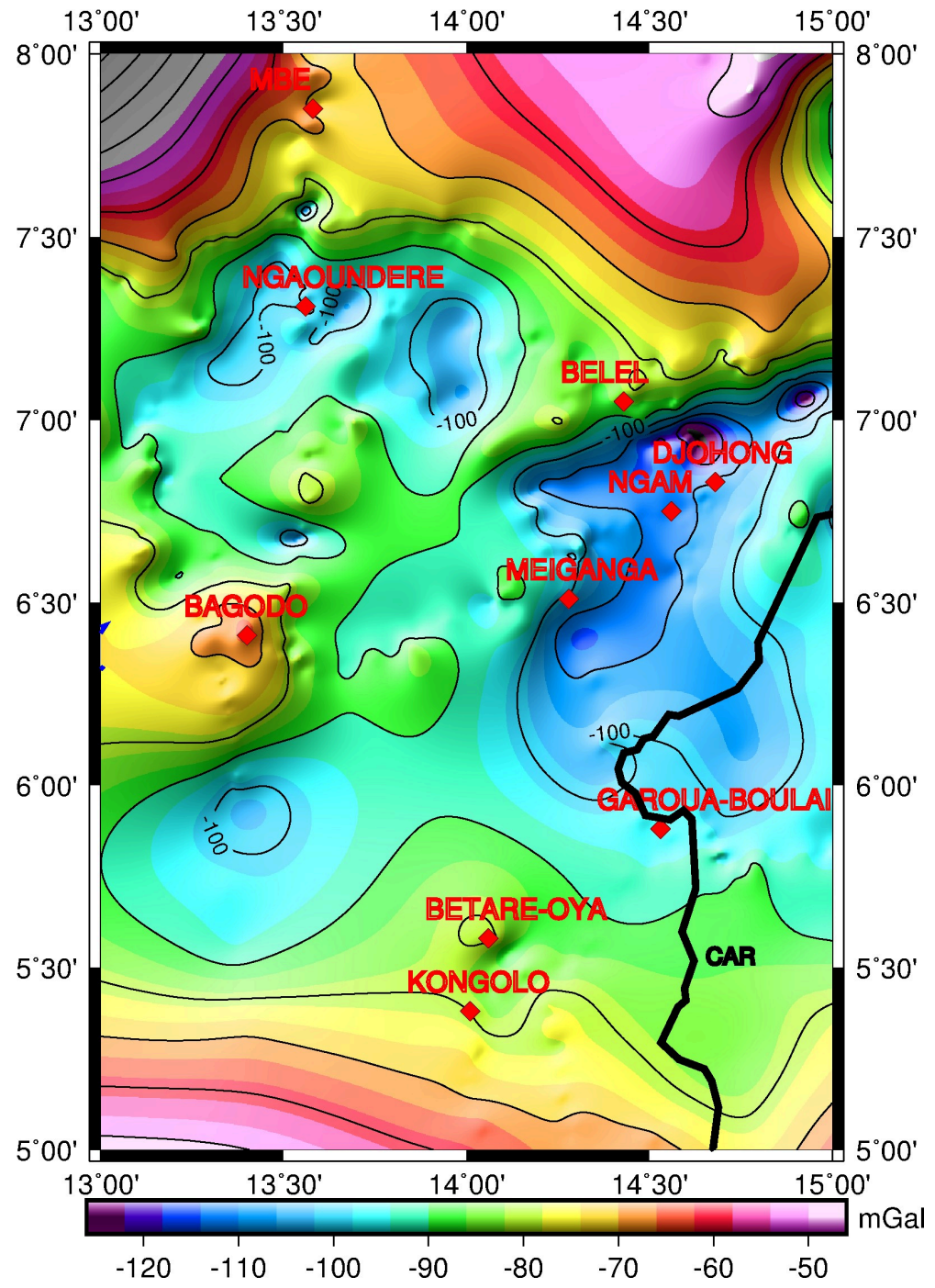

Figure 3. Bouguer anomaly map of the region obtained by using terrestrial gravity data.

Meiganga, covers the entire city of Ngaoundere. An overview of the configuration of anomalies shows a dominant direction NE-SW, which corresponds to the large fault that extends from Foumban to the Mbere Ditch. The magnitude of these anomalies is approximately $-100 \mathrm{mGal}$ with minimums reaching -120 mGal. They can be interpreted as the effect of low density formations. The second sector, situated in the southern part of the study area consists of heavy gravity anomaly. This anomaly with amplitude of about $-50 \mathrm{mGal}$ can be link to the presence of dense rocks in this sector. The third sector, situated in the northern part of the region, between parallels $7.30^{\circ}$ to $8^{\circ} \mathrm{N}$, which covers the Ngaoundere mountain zone is characterized by negative anomaly $(-75 \mathrm{mGal})$ with dominant EW trend. This anomaly does not indicate any geological formation, because the zone is composed of basaltic rocks inside the basement. It is due probably either to the lack of gravity data in the region, or the effect of neighboring formations. The orientation of iso-lines of anomalies in this zone does not objectively identify the direction of the Ngaoundere mountain. The 
Bouguer anomaly map shows some limitations making a difficult to do the proper gravity investigations. The structure of Adamawa plateau remains poorly knows. To solve this problem, terrestrial gravity data must undergo using data from the global geopotential model GGM02C [7] [23].

\subsection{Global Geopotentiel Model: GGM02C}

In this part of study data from the Global Geopotential Model were used [23] [24]. The GGM02C model has been publicly released by Deutsches Zentrum für Luftund Raumfahrt (DZLR). This model has several advantages: (1) It provides good information in areas previously inaccessible or having terrestrial data gaps and extends across natural and artificial boundary; (2) it incorporates data from different sources including satellite altimetry over oceans, satellite gravity and the terrestrial gravity [20]. In addition, this model represents better the gravity anomalies in the Adamawa plateau. The GGM02C model is complete to spherical harmonic degree and order 200 [7] [8] [25]. The data are first obtained as free-air gravity anomalies and then corrected to underline topographic effects using a Digital Elevation Model (DEM) GLOBE [24]. A reduction density of 2.67 $\mathrm{g} / \mathrm{m}^{3}$ was used for the Simple Bouguer correction. According to [7] [8], the GGM02C gravity data and terrestrial ones have the same precision; so they are stackable and can be superimposed. The better coverage of gravity data has undoubtedly permitted us to draw a better simple Bouguer anomaly map of the region. This map has strengthened some hypotheses already supported by the geological data but not addressed by previous geophysical studies carried out in the study area so far. The orientation of the anomalies agrees well with the overall direction of the tectonic and geological structures. Same as the previous map, the Bouguer anomaly map obtained by combination of terrestrial and GGM02C gravity data (Figure 4) reveals three gravity sectors.

The first sector, located in the middle part of the study area is constituted by negative anomaly with NE-SE direction that goes from Betare-Oya to Djohong passing through Graoua-Boulai and covers the entire city of Ngaoundere and Belel. This anomaly with amplitude of $-120 \mathrm{mGal}$ can be considered as the effect of the low densities formations. In this sector heavy anomalies $(-20$ to -30 $\mathrm{mGal}$ ) appear in the Mbere basin area. The shape of these anomalies indicates that they would have been affected by folding which occurred during different tectonic phases that have affected the region [26]. The presence of heavy anomalies with NE-SO direction is due to the presence of dense formations under the sedimentary environment. These results are in agreement with geological observations which show that the entire sedimentary series is swung northward [13] [14]. The second sector that covers the south-west of Kongolo is characterized by heavy anomalies $(-40 \mathrm{mGal})$ indicating the presence of dense formations. It is composed mainly of migmatic rocks. The third sector, which situated in the south of Mbe and covers the Volcanic mountain zone, consists of heavy anomalies $(-20 \mathrm{mGal})$ and weak anomalies $(-140 \mathrm{mGal})$ with NE-SO direction. This 


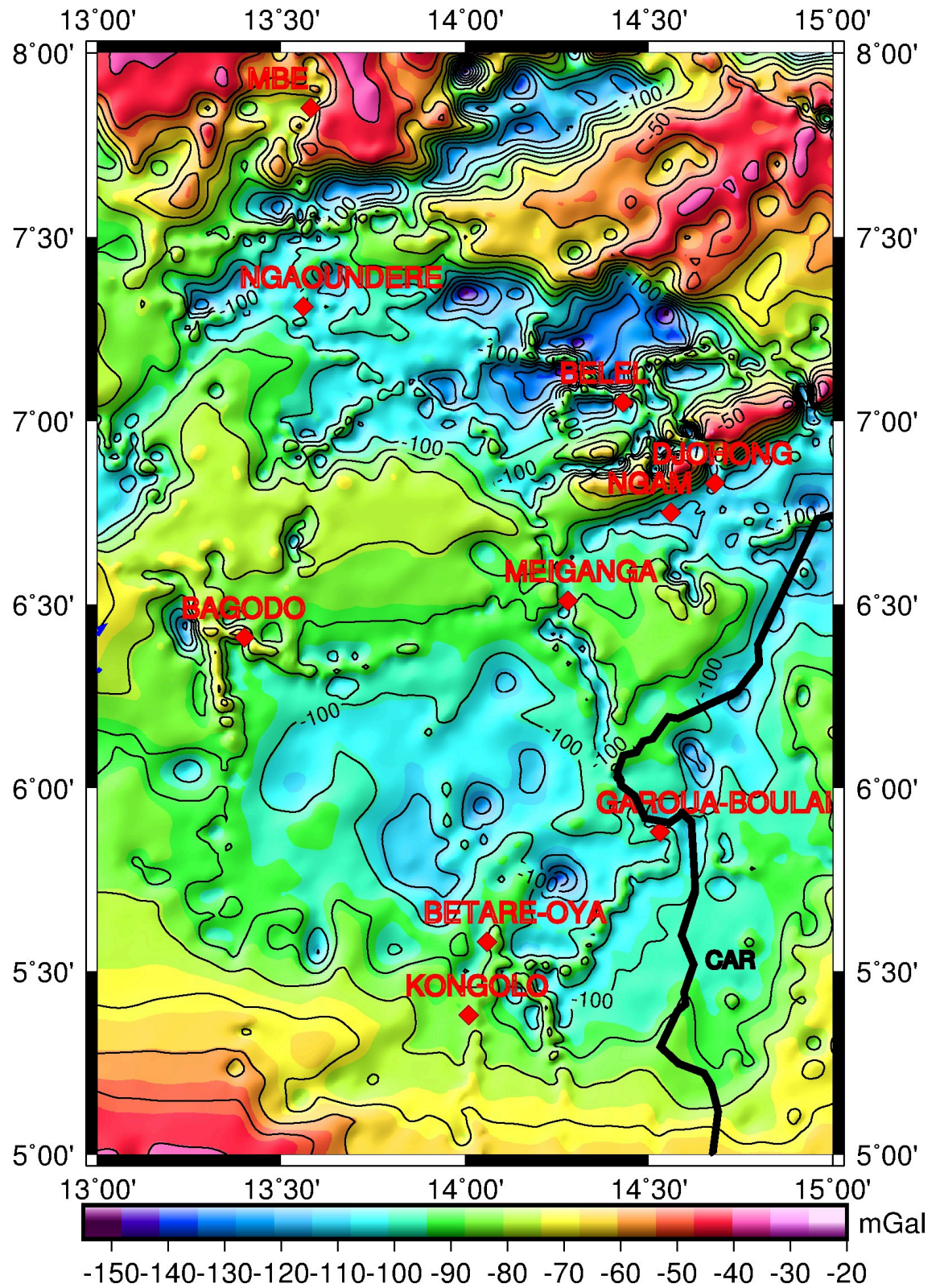

Figure 4. Bouguer anomaly map of the region obtained after densification of gravity data.

map shows that weak anomalies appear in the central part of the massif. These anomalies are due to the collapsing of the crust or are due to the presence of granitic rocks constituting the socle. Heavy anomalies appear in the northern and southern slope of the mountain corresponds to the basaltic intrusion in this area. The direction of anomalies in this map is visibly more developed than that before densification. This direction coincides perfectly with ENE-WSW direction of the Adamawa Plateau and suggests that the intrusion could have been controlled by the tectonic processes.

In gravity method, the Bouguer anomaly map generally overshadow the effects of density contrasts, deep and shallow, wide and local. Regional-residual separation allows to isolate the anomaly due to deep sources and extended than 
those from density contrast reduced and shallower extension. This separation was made in our previous works and the residual of order 5 was the best amenable for the geological structures near surface in the Adamawa plateau [7]. In the present work the residual of order 5 will be exploited.

The regional anomaly map (Figure 5 ) is characterized by a negative gravity anomaly in the center bounded by gradients increasing towards the north. These observations show that the basement is deepening towards the south of the region. Indeed, using geophysical analysis of gravity data, the crustal thickness beneath the northern edge of the Adamawa plateau is about $23 \mathrm{~km}$ and $33 \mathrm{~km}$ in the north and south respectively [5] [27]. We noticed that, the regional Bouguer

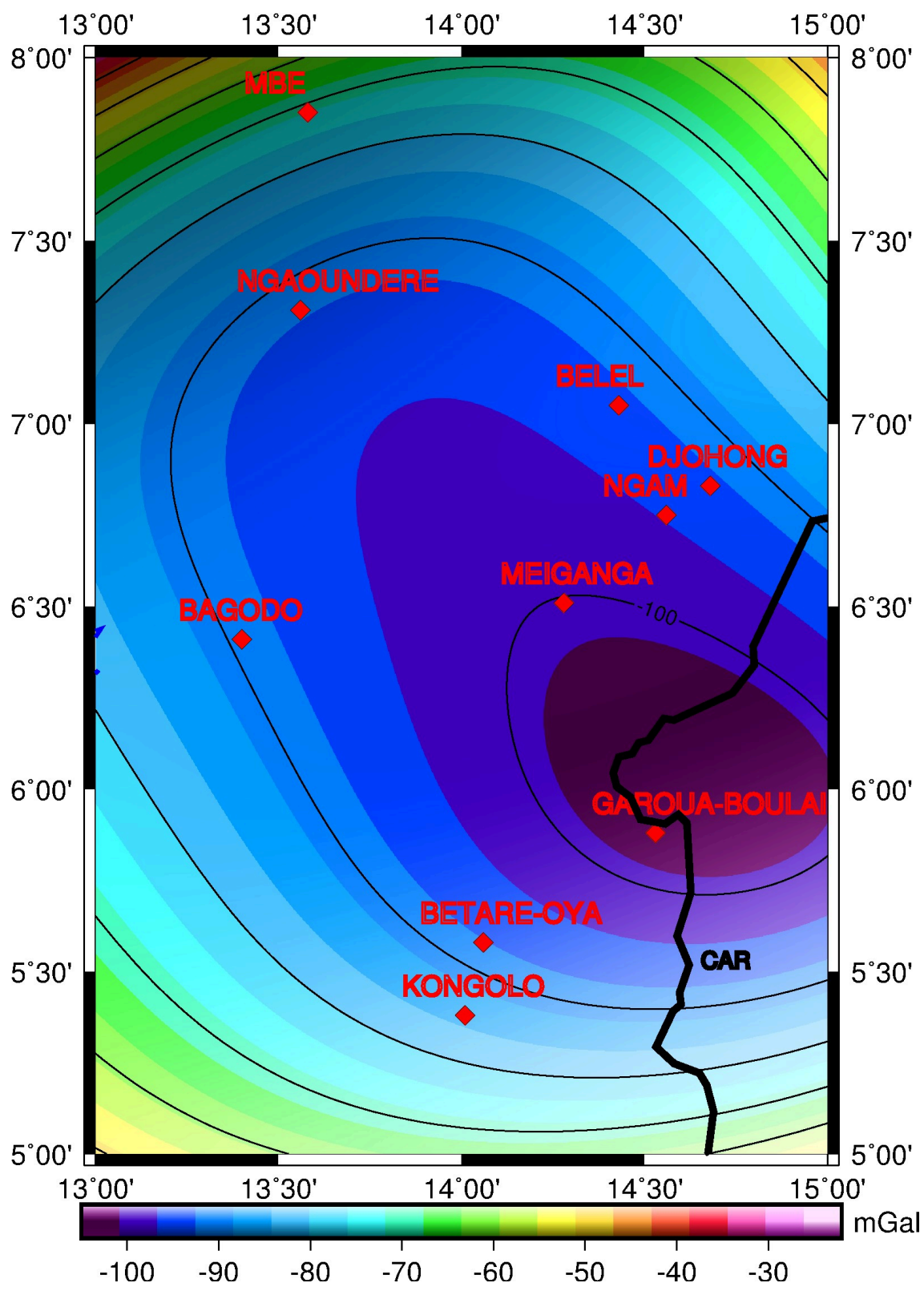

Figure 5. Fifth-order of regional Bouguer anomaly map of the region obtained after densification of the gravity data. 
anomaly is dominated by the effect of structures located beyond the Moho. At the level of Mbe the iso-lines of anomalies were NE-SW direction then passed EW to ESE-WNW in the center of study area. This multiple direction of isolines indicates that the basement has found at great depth [13] [16]. To the east of meridian $6^{\circ} \mathrm{N}$, the region is constituted by the $-100 \mathrm{mGal}$ contour line within which is Garoua-Boulai and Meiganga. This contour line is close and represents the thinning of the lithosphere due to asthenospheric uplift under the Adamawa [2] [27].

Residual Bouguer anomaly map of the study area (Figure 6) shows two different sectors: positive sector and negative sector which amplitudes are respectively ( +40 and $-70 \mathrm{mGal}$ ). The positive sector is founded between Ngaoundere

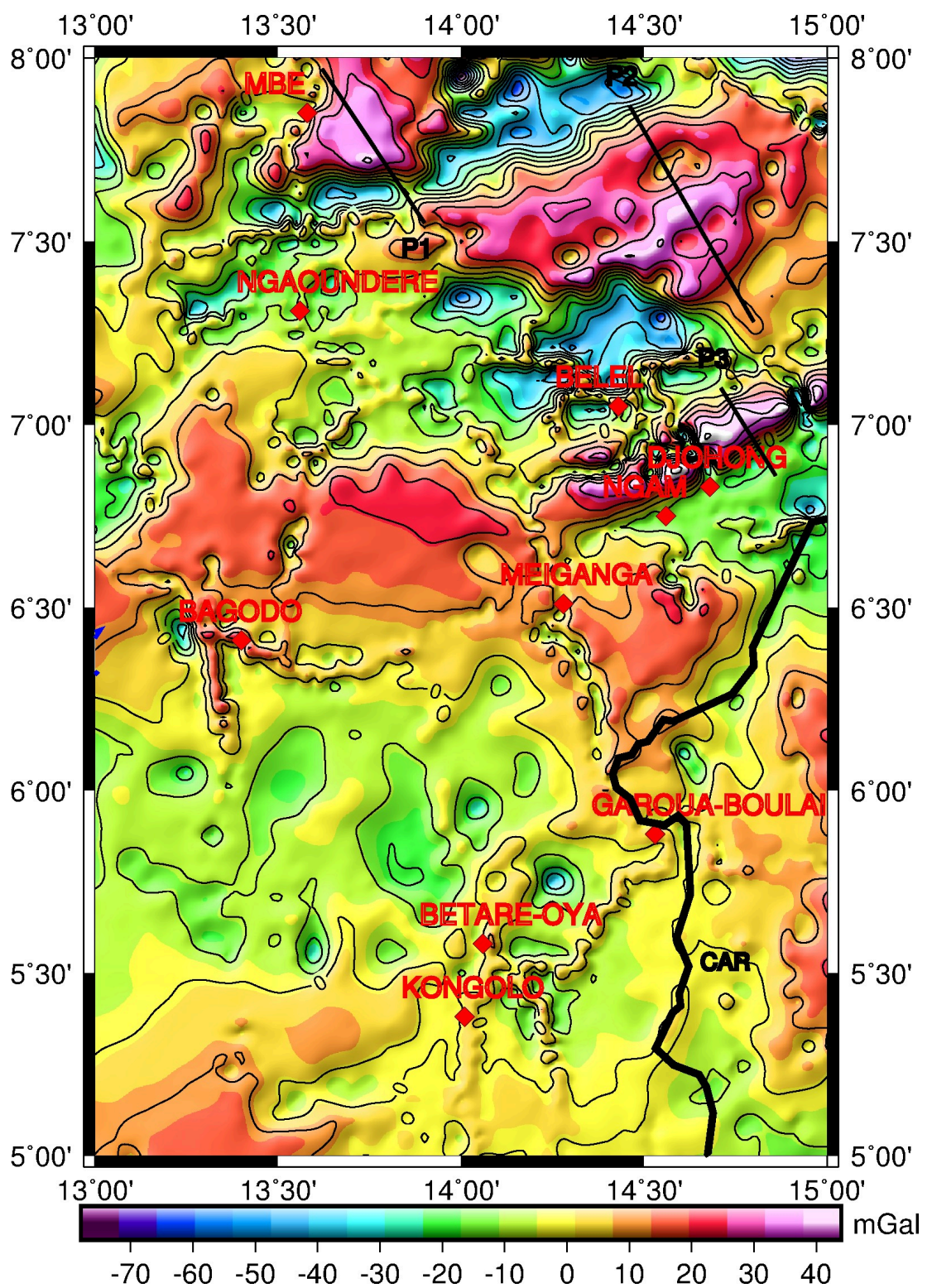

Figure 6. Fifth-order of residual Bouguer anomaly map of the region obtained after densification of gravity data. 
and Mbe (P1), north-east of Ngaoundere (P2) and north-east of Djohong (P3) localities indicates uplift basement and lateral high dense rocks. In geological considerations, at level of Djohong the positive residual Bouguer anomaly is assigned to the thinning down of the crust on the one hand and on the other hand to the existence of invisible basaltic rocks under the granite-gneisses basement. Between Ngaoundere and Mbe and north-east of Ngaoundere, the positive anomaly corresponds to the intrusion of dense rock of high density under the low density formation. The negative sector observed around Ngaoundere and north of Belel trending NE-SW. A comparison of this negative anomaly with the geological map shows that, this anomaly is due to the collapsing of the crust and the effect of low density formation. In south and east of Mbe, three peaks of negative anomalies appear in the central part of the massif, the average value of these Bouguer anomalies is $-30 \mathrm{mGal}$. In general Bouguer anomalies are usually negative in the massif and mountains because of the isostasy. The rock density of their root is lower than that of the surrounding earth's mantle. The presence of these peaks of anomalies indicates that, the massif has a variable thickness and is more rooted in these areas than elsewhere. The setting of this massif is linked to a general collapse of the socle in the region. The positive and negative sector is separated by a steep gradient, which corresponds to the effect of discontinuity between two different structures. In order to provide more information in the study area and to show the capability of densified data to detect unknown geological structures, spectral analysis and 3D density inversion based on the geological map were used along three profiles drawn on the residual Bouguer anomaly map.

\section{Method}

\subsection{Power Spectrum Analysis}

Spectral analysis as described by [28] is a technical method based on the property of the energy spectrum of the gravity data. It estimates the depths of perturbing bodies. Generally extended anomaly with amplitude which decreases rapidly is characterized by high frequency. However, large anomaly which amplitude decreases slightly is characterized by low frequency spectrum [29] [30]. The estimation of the depths is controlled by the choice of the line defining the slopes. When the energy spectrum logarithm is plotted versus wavenumber, we choose the straight-line segments whose slopes are proportional to the depth of the perturbing body according to the following relation [31] [32]:

$$
h=\Delta \log E / 2 \pi \Delta k
$$

where $\Delta \log E$ is the variation of the logarithm of the energy spectrum $\Delta k$ a wavenumber and $h(\mathrm{~km})$ is the depth of perturbing bodies. In this case, $\mathrm{h} 1$ corresponds to the deep density contrast plane and h2: shallow density contrast plane. According to [33] the errors value on each profile is $5 \%$ of the mean depth value. 


\subsection{D Density Inversion}

For 3D density inversion of the structures in the Adamawa plateau we used GRABLOX2 (version 2.1) by [34]. This program calculates the gravity field for 3D block model. A block model is a block divided into cubes. For each cube we note constant density. The program uses two methods: Occam inversion and Singular Value Decomposition (SVD) [35]. For each method there are three options for setting the model (density, height and density + height) [9] [10]. Occam inversion needs to solve much larger matrix system than the SVD. The SVD inversion creates a smooth and continuous model if the gravity data are dense. In such situations the Occam inversion gets unstable and generates very rugged structures. In this study, the Singular Value Decomposition will be used for 3D density inversion. The coefficients of the base of anomaly can be optimized separately for the gravity and gradient data. Spectral analysis is used to constrain depths of bodies responsible for positives anomalies which correlated to the surface geology. The residual and regional anomalies were read with separated format. The inversion will resolve residual density where the mean density of the modeled volume should be added to give geologically realistic density values. For our study densities of the blocks fixed by recent works [9] are used to define the initial model. In this case, the background value should be set to the mean of the density value used in Bouguer corrections $\left(2.67 \mathrm{~g} / \mathrm{m}^{3}\right)$. We used Grablox2 program to optimize densities of the minor blocks model then compare it with the observed Bouguer anomaly. When the observed and calculated Bouguer anomaly is realized, the inversion is obtained. After inversion the distribution of the densities inside the resulting blocks models can be used in geological interpretations.

\section{Results and Discussions}

\subsection{Power Spectrum Analysis}

To estimate the average depths of perturbing bodies responsible for gravity data, we used spectral analysis of three profiles (P1, P2, P3) drawn on the residual Bouguer anomaly map. These profiles are executed perpendicular to the main direction of the structure under study and crossed largely the zone where the structure is suspected [29]. For the three previous profiles Figure 7 presented the power spectrum curves. Two major discontinuities of densities have been identified, the first h1 represents the low frequency associated to deep-seated bodies and h2 represents the high frequency causes by bodies near surface. The deepest discontinuity result of profile P1, P2 and P3 are $8.64 \mathrm{~km}, 14.41$ and 5.80 $\mathrm{km}$ respectively for a mean of $9.62 \mathrm{~km}$. These depths could be correspond to the Moho depth in the study area. These results agree with those obtained by [33]. According to this author, the discontinuity of structure in the Adamawa uplift is between 7 and $13 \mathrm{~km}$ (with a mean of $11 \mathrm{~km}$ ). Our result and those obtained by [33] have few differences.

The depths obtained by [33] are based on only terrestrial gravity data while 

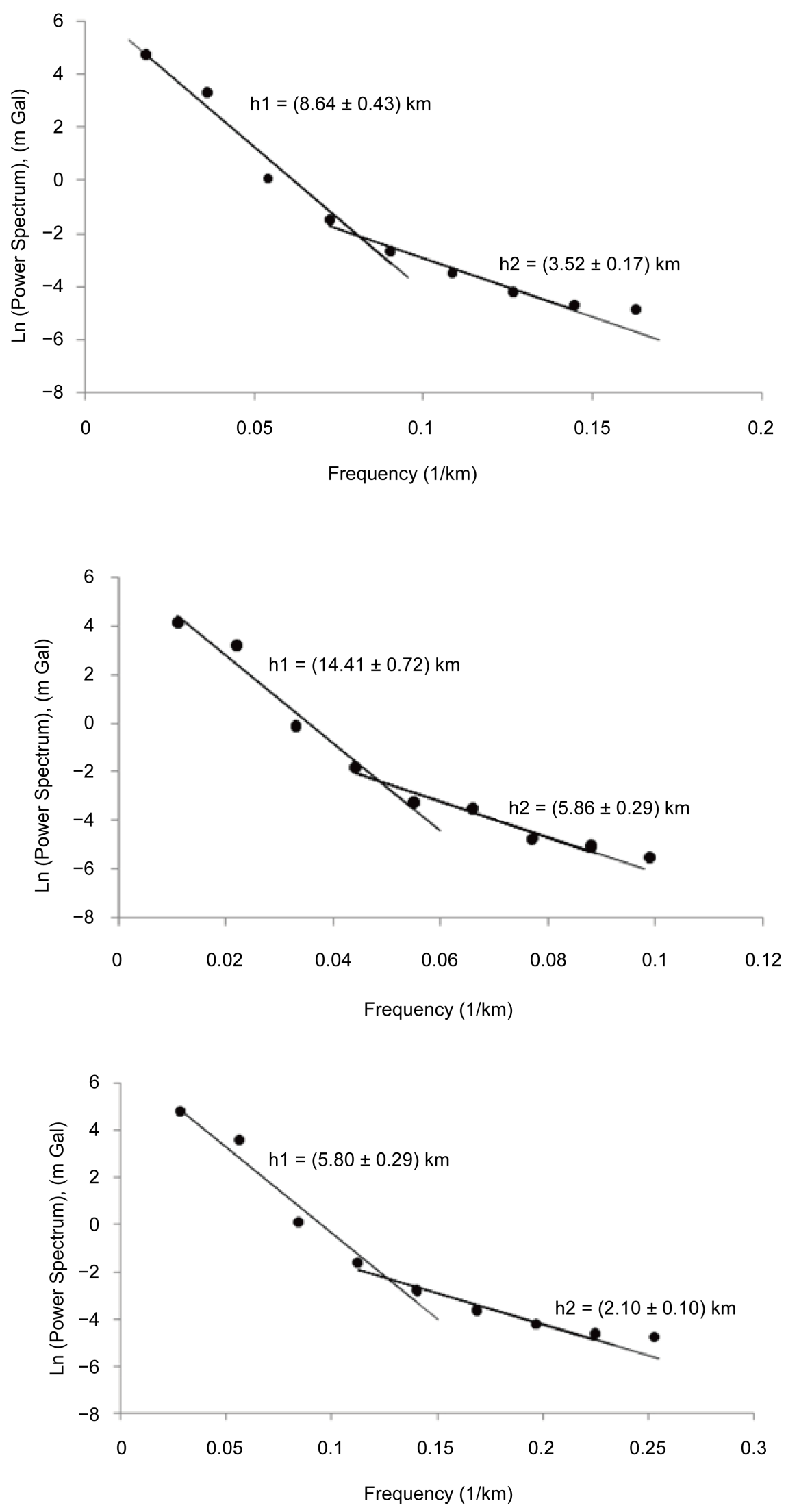

Figure 7. Power spectrum of profiles P1, P2 and P3 from spectral analysis program. 
our results are integrating new gravity data in the existing. The second discontinuity associated with the shallowest depths for profiles P1, P2 and P3 is respectively $3.52 \mathrm{~km}, 5.86$ and $2.10 \mathrm{~km}$ for a mean of $3.83 \mathrm{~km}$. This value indicates that the sources of anomalies are not deep in the sedimentary basin. These depths are probably due to the base of Mbere sedimentary basin which could be associated with volcanic intrusions due to the positive gravity anomaly. These bodies may be due to the intrusions of dense materials in the basement and could be the boundary between the lower crust and the upper crust. The depths of $3.83 \mathrm{~km}$ and $9.62 \mathrm{~km}$ are the new values of depths obtained for futures investigations in the Adamawa plateau.

\subsection{D Density Inversion}

The 3D density inversion was obtained using three profiles P1, P2 and P3 trending NE-SE. This inversion informs us to the structure of the Adamawa Plateau.

The structural model associated with profile (P1) (Figure 8) consists of three
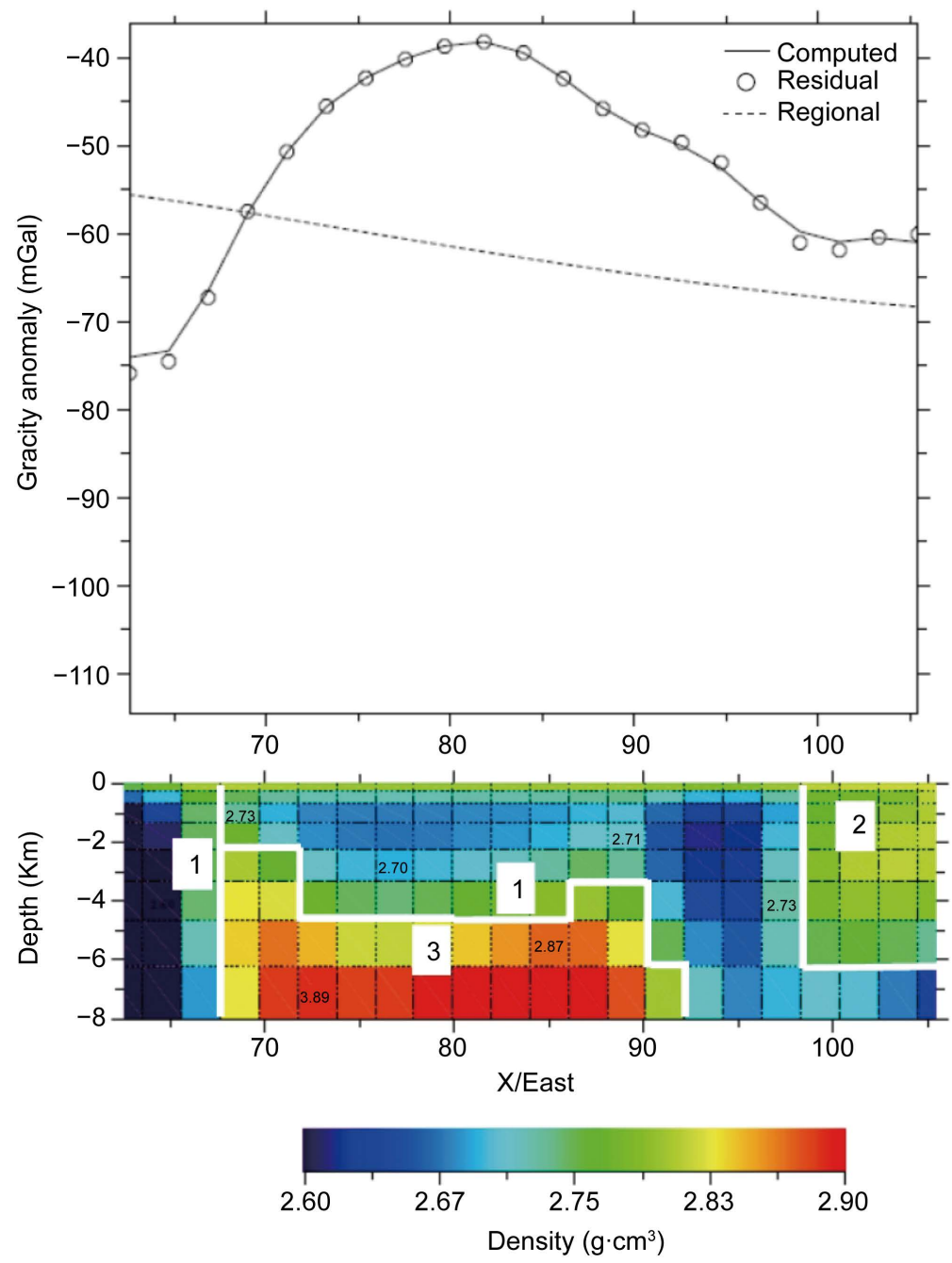

Figure 8. Interpreted 3D density model of profile (P1) from Grablox2 program showing different formations: 1: Granites; 2: Gneisses; 3: Basaltic rocks. 
bodies with different compositions. The first body (1) with lower densities between $2.60 \mathrm{~g} / \mathrm{m}^{3}$ and $2.73 \mathrm{~g} / \mathrm{m}^{3}$ is situated at $5 \mathrm{~km}$ in the middle and $8 \mathrm{~km}$ in the north and south of the model. This formation corresponds to the granitic rock under the crust which the signature is due to the negative Bouguer anomalies observed in this zone. The second body (2) located at the end of the model has a lateral extension and roof that can reach $4 \mathrm{~km}$. This formation with densities ranging from $2.75 \mathrm{~g} / \mathrm{m}^{3}$ to $2.78 \mathrm{~g} / \mathrm{m}^{3}$ can be associated to the gneisses formations. The third body (3) extended laterally beneath the granites in the study area has high density between $2.8 \mathrm{~g} / \mathrm{m}^{3}$ and $2.8 \mathrm{~g} / \mathrm{m}^{3}$. This body corresponds to the basaltic intrusion which the signature is due to positive gravity anomaly observed on the Bouguer anomaly map.

The structural model of the second profile (P2) (Figure 9) consists of three bodies with different shapes, positions and thicknesses. The body (1) starts and
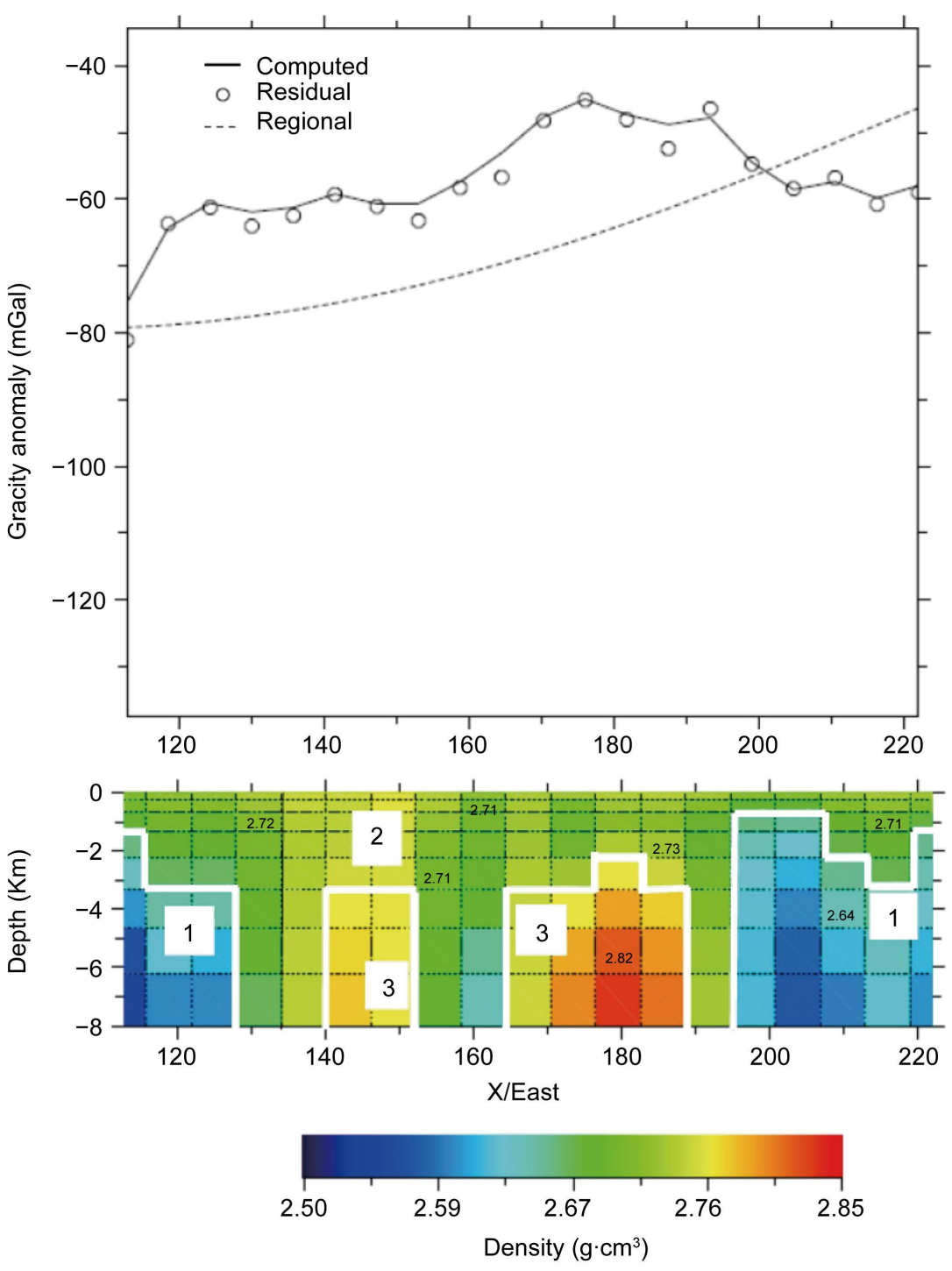

Figure 9. Interpreted 3D density model of profile (P2) from GRABLOX showing different formations: 1: Granites; 2: Gneisses; 3: Basaltic rocks. 
ends of the model, is constituted with lower density ranging from $2.60 \mathrm{~g} / \mathrm{m}^{3}$ to $2.73 \mathrm{~g} / \mathrm{m}^{3}$. This body corresponds to the granitic intrusion at great deep with an extension of about $40 \mathrm{~km}$. The second body (2) with density ranging from 2.75 $\mathrm{g} / \mathrm{m}^{3}$ to $2.78 \mathrm{~g} / \mathrm{m}^{3}$ designed gneisses formations in the basement of the study area. This body begins from surface area and reaches at $8 \mathrm{~km}$ in the middle of the model. A layer with density between $2.80 \mathrm{~g} / \mathrm{m}^{3}$ and $2.90 \mathrm{~g} / \mathrm{m}^{3}$ corresponds to the high basement structure body (3) located in the middle of the model. This body constitutes the main pluton of the complex, extends laterally at depth beyond the gneisses and corresponds to the basaltic formations. These formations have been put in place with the aid of the asthenospheric rise which leads to a lithospheric bulge. They are responsible for the positive Bouguer anomaly observed in this area.

Like the other profiles, the general features of profile (P3) (Figure 10) have three principal bodies. The first body (1) with lower density ranging from 2.20 to

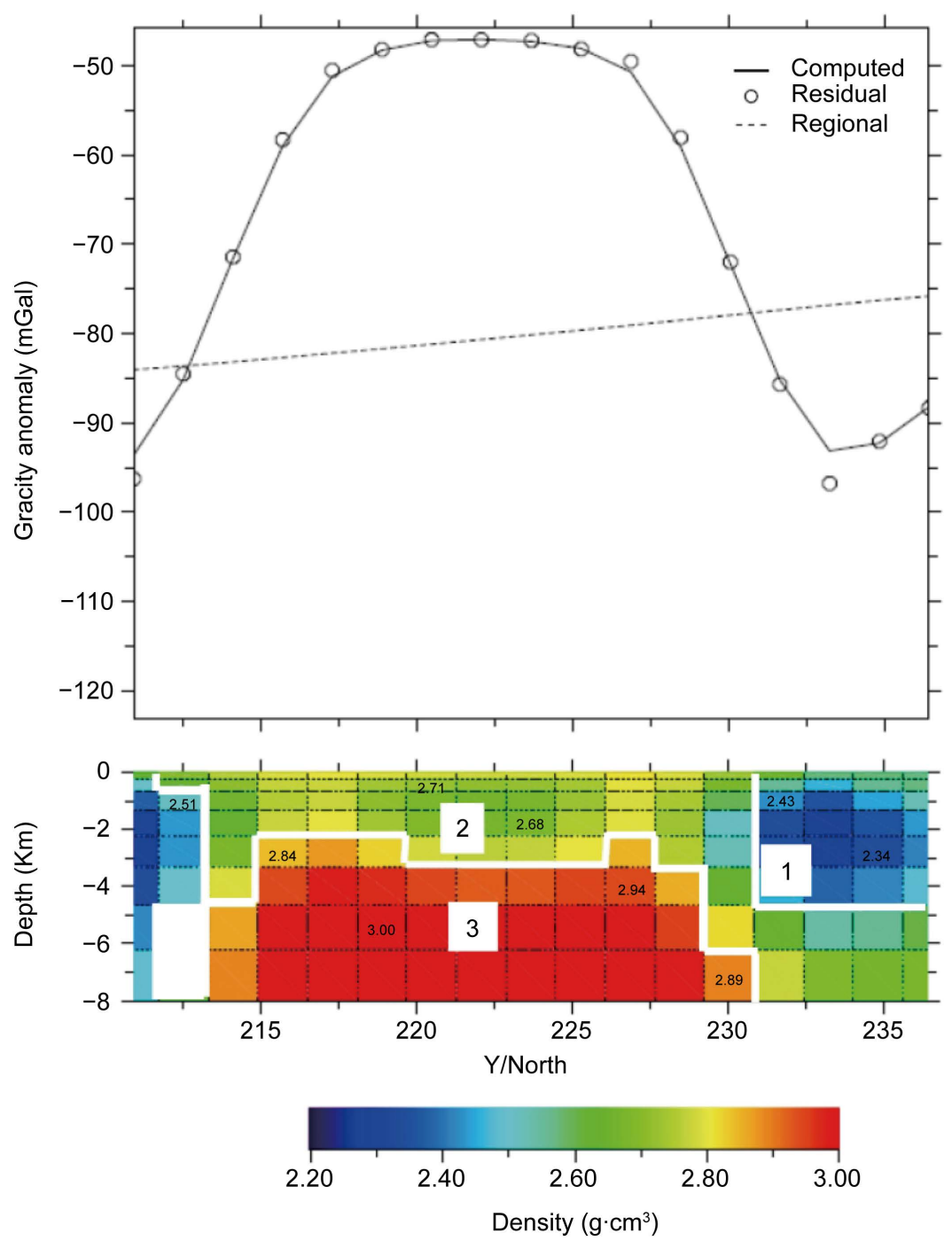

Figure 10. Interpreted 3D density model of profile (P3) from GRABLOX showing different formations: 1: Sedimentary formations; 2: Granites; 3: Basaltic rocks. 
$2.45 \mathrm{~g} / \mathrm{m}^{3}$ is located in the north and south extremity of the model. This body begins at $6 \mathrm{~km}$ and $4 \mathrm{~km}$ respectively at the start and at the end of model. The negative Bouguer anomaly observed in the northern and southern border of the profile can be attributed to the sedimentary deposit with low density in the study area. The second body (2) with density ranging from 2.68 to $2.78 \mathrm{~g} / \mathrm{m}^{3}$ in the middle of the model can be associated with gneiss formation. This formation is at the origins of the positive Bouguer anomaly observed in this zone and related the crustal thickening of the region followed by the fracturing which must have lead to the collapse of large blocks of crust with dimensions of several kilometers. The third body (3) with density between $2.84 \mathrm{~g} / \mathrm{m}^{3}$ and $3.00 \mathrm{~g} / \mathrm{m}^{3}$, corresponds to the main pluton of the complex and extends laterally at depth beyond granites. This body with high density has a depth beyond $6 \mathrm{~km}$ and an extension of about $18 \mathrm{~km}$ under the basement. This body is interpreted as a rise of the basaltic rocks in the socle. It generates a positive Bouguer anomaly observed in this area and it installation is carried out in the following way: During a volcanic eruption, the magma crystallizes in deep into magmatic pockets without completely crossing the crust. In this study we observed a spectacular ascent of magmatic rocks, whose roof is about $2.5 \mathrm{~km}$. The topographic expression of this process is the formation of the Adamawa plateau which is accompanied by brittle tectonics characterized by cracks and fractures.

\section{Conclusion}

In this work, the main objective is to analyze the new Bouguer anomaly map and to determine the depth and density of subsurface structure of the Adamawa plateau by using combined gravity data. The resulting residual Bouguer anomaly map shows positive and negative anomaly. Positive residual anomalies are due to the basaltic structures under granite-gneisses basement while negative gravity anomalies are due to the granite formations or the sedimentary basin. Spectral analysis and 3D density inversion show the depths and densities of geological structures associated with the positive residual Bouguer anomaly. The depths of $3.83 \mathrm{~km}$ and $9.62 \mathrm{~km}$ are the new values of depths obtained for futures investigations in the study area. This area is composed by granitic formation with density ranging from 2.60 to $2.73 \mathrm{~g} / \mathrm{m}^{3}$, sedimentary formation with density ranging from 2.20 to $2.45 \mathrm{~g} / \mathrm{m}^{3}$, gneisses and basaltic rocks with density between 2.75 to $2.78 \mathrm{~g} / \mathrm{m}^{3}$ and 2.84 to $3.0 \mathrm{~g} / \mathrm{m}^{3}$ respectively. Our results contain more additional information than those obtained from terrestrial gravity data. Some recent models such as GOCE are also available, but have not yet been fully tested in the study area. For future investigation we will compare several field models from GOCE to choose the one that represents the best gravity data in order to improve the gravity analysis in the Adamawa plateau.

\section{Acknowledgements}

The authors would like to thank Markku Pirttijärvi (Universty of Oulu Finland) 
for helpful the 3D density inversion and Late Henry Duquenne (LAREG, France) for putting at our disposal the GGM program. The authors also acknowledge all the reviewers for their constructive comments.

\section{References}

[1] Poudjom-Djomani, Y.H., Diament, M. and Albouy, Y. (1992) Mechanical Behaviour of the Lithosphere beneath the Adamawa Uplift (Cameroon, West Africa) Based on Gravity Data. Journal of Africa Earth Sciences, 15, 81-90. https://doi.org/10.1016/0899-5362(92)90009-2

[2] Poudjom-Djomani, Y.H. (1993) Apport de la Gravimétrie à l'Etude de la Lithosphère Continentale et Implications Géodynamiques. Etude d'un Bombement Intraplaque: Le Massif de l'Adamaoua (Cameroun). Thèse Doctorat/PhD, Université de Paris-Sud, $229 \mathrm{p}$.

[3] Poudjom-Djomani, Y.H., Nnange, J.M., Diament, M., Ebinger, C.J. and Fairhead, J.D. (1995) Effective Elastic Thickness and Crustal Thickness Variations in West Central Africa Inferred from Gravity Data. Journal of Geophysical Research, 100, 22.047-22.070.

[4] Noutchogwe, T.C. (2010) Investigation Géophysique dans la Région de l'Adamaoua par les Méthodes Gravimétriques et Magnétiques: Implications Structurales et Hydrogéologiques. Thèse Doctorat/PhD, Université de Yaoundé I, 146 p.

[5] Poudjom-Djomani, Y.H., Diament, M. and Wilson, M. (1997). Lithospheric Structures across the Adamawa Plateau (Cameroon) from gGavity Studies. Tectonophysics, 273, 317-327. https://doi.org/10.1016/S0040-1951(96)00280-6

[6] Merry, C.L. (2003) The African Geoid Project and its Relevance to the Unification of African Vertical Reference Frames. 2nd FIG Regional Conference, Marrakech, Morocco, 2-5 December 2003.

[7] Bouba, A., Kamguia, J., Nouayou, R. and Tabod, C.T. (2016) Relation between Geological Features and Geophysical Signatures of the Adamawa Plateau (Cameroon) from Combined Terrestrial Gravity Measurements and GRACE Model. Earth Sciences Research Journal'unpublished'.

[8] Kamguia, J., Tabod, C.T., Nouayou, R., Tadjou, J. M., Manguelle-Dicoum, E. and Kande, H.L. (2007) The Local Geoid Model of Cameroon CGM05. Nordic Journal of Surveying and Real Estate Research, 4, 7-23.

[9] Shandini, N.Y., Tadjou, J.M., Tabod, C.T. and Fairhead, J.D. (2010) Gravity Data Interpretation in the Northern Edge of the Congo Craton (South-Cameroon). Anuário does Instituto de Geociências, 33, 73-82.

[10] Basseka, C.A., Shandini, Y. and Tadjou, J.M. (2011) Subsurface Structural Mapping using Gravity data of the Northern Edge of the Congo Craton, South Cameroon. Geofisica, 28, 229-245.

[11] Deruelle, B., Ngounouno, I. and Demaiffe, D. (2007) The Cameroon Hot Line (CHL): a Unique Example of Active Alkaline Intraplate Structure in Both Oceanic and Continental Lithospheres. Comptes Rendus de Geosciences, 339, 589-600. https://doi.org/10.1016/j.crte.2007.07.007

[12] Colligon, F. (1968) Gravimétrie de Reconnaissance de la République Fédérale du Cameroun, Orstom Paris, 35 p.

[13] Dumont, J.F. (1987) Etude Structurale des Bordures Nord et Sud du Plateau de l'Adamaoua: Influence du Contexte Atlantique. Géodynamique, 1, 9-13.

[14] Marechal, A. and Vincent, P.R. (1971) Le Fossé Crétacé du Sud Adamaoua 
(Cameroun). Cahier d'ORSTOM Série Géologique, 3, 67-83.

[15] Kampunzu, A.B., Caron, J.H. and Lubala, R.T. (1986) The East African Rift Magma Genesis and Astheno-lithospheric Dynamism. Episodes, 9, 211-216.

[16] Noutchogwe, T.C., Tabod, C.T. and Manguelle-Dicoum, E. (2006) A Gravity Study of the Crust Beneath the Adamawa Fault Zone, West Central Africa. Journal of geophysics and Engineering, 3, 82-89. https://doi.org/10.1088/1742-2132/3/1/009

[17] Gèze, B. (1941) Sur les Massifs Volcaniques du Cameroun Occidental. Comptes rendus de l'Académie des Sciences de Paris, 212, 498-500.

[18] Ngako, V., Jegouzo, P. and Nzenti, J.P. (1991) Le Cisaillement Centre Camerounais Rôle Structural et Géodynamique dans l'Orogénèse Panafricaine. Comptes Rendus de 1 Académie des Sciences de Paris, 313, 457-463.

[19] De Almeida, F.F.M., Hasui, Y., Brito, N.B.B. and Fuck, R. (1991) Brasiliano Structural Provinces: An Introduction. Earth Science Reviews, 17, 1-29. https://doi.org/10.1016/0012-8252(81)90003-9

[20] Benkhelil, J. and Guiraud, R. (1980) La Bénoué (Nigéria): Une chaîne Intracontinentale de Style Atlasique. Comptes Rendus de l'Académie des Sciences de Paris, 290, 1517-1520.

[21] Louis, P. (1970) Contribution Géophysique à la Connaissance Géologique du Bassin du Lac Chad, Mémoire ORSTOM, Paris, France, 311 p.

[22] Wessel, P. and Smith, W.H.F. (1995) New Version of GMT Released. Transactions of the American Geophysical Union, 76, 7 p.

[23] Tapley, B., Ries, J., Bettadpur, S., Chambers, D., Cheng, M., Condi, F., Gunter, B., Kang, Z., Nagel, P., Pastor, R., Pekker, T., Poole, S. and Wang, F. (2005) GGM02 An Improved Earth Gravity Field from GRACE. Journal of Geodesy, 79, 11 p.

[24] Hastings, D.A. and Dunbar, P.K. (1998) Development and Assessment of the Global Land One-Kilometer Base Elevation Digital Elevation Model (GLOBE). International Society of Photogrammetry and Remote Sensing, $4 \mathrm{p}$.

[25] Kamguia, J., Nouayou, R., Tabod , C.T., Tadjou, J.M., Manguelle-Dicoum, E. and Kande, H.L. (2008) Geophysical Signature of Geological Units Inferred from the Analysis of Geoid Maps in Cameroon and Its Surroundings. Journal of African Earth Sciences, 52, 1-8. https://doi.org/10.1016/j.jafrearsci.2008.02.002

[26] Njanko, T. (1999) Les Granitoïdes Calco-alcalins Syn-cisaillement de la Région de Tibati (Domaine Central de la Chaîne Panafricaine): Signification Géodynamique par Rapport à la Tectonique Panafricaine (Cameroun). Thèse de Doctorat 3eme cycle, Université de Yaoundé I.

[27] Dorbath, L., Dorbath, C., Fairhead, J.D. and Stuart, G.W. (1986) A Teleseismic Delay Time Study across the Central African Shear Zone in the Adamawa Region of Cameroon, West Africa. Geophysical Journal Royal Astronomical Society, 86, 751766. https://doi.org/10.1111/j.1365-246X.1986.tb00658.x

[28] Spector, A. and Grant, F. S. (1970) Statistical Models for Interpreting Aeromagnetic Data. Geophysics, 35, 293-302. https://doi.org/10.1190/1.1440092

[29] Tadjou, J.M., Nouayou, R., Kamguia, J., Kande, H.L. and Manguelle Dicoum, E. (2009) Gravity Analysis of the Boundary between the Congo Craton and the PanAfrican belt of Cameroon. Austrian Journal of Earth Sciences, 102, 71-79.

[30] Zanga-Amougou, A., Ndougsa-Mbarga, T., Meying, A., Layu, D.Y., Bikoro-Bi-Alou M. and Manguelle-Dicoum, E. (2013) 2.5D Modeling of Crustal Structures along the Eastern Cameroon and Western Central African Republic Derived from Finite Element and Spectral Analysis Methods. Geophysica, 49, 75-97. 
[31] Gerard, A. and Debeglia, N. (1975) Automatic Three-Dimensional Modeling for Interpretation of Gravity or Magnetic Anomalies. Geophysics, 40, 1014-1034. https://doi.org/10.1190/1.1440578

[32] Inoue, H. (1986) A Least-Squares Smooth Fitting for Irregularity Spaced Data: Finite Element Approach Using the Cubic B-Spline Basics. Geophysics, 51, $2051-$ 2060. https://doi.org/10.1190/1.1442060

[33] Nnange, J.M., Ngako, V., Fairhead, D. and Ebinger, C.J. (2000) Depths to Density Discontinuities Beneath the Adamawa Plateau Region, Central Africa, from Spectral Analysis of Terrestrial Gravity Data. Journal of African Earth Science, 40, 887-901. https://doi.org/10.1016/S0899-5362(00)00058-0

[34] Markku, P. (2014) Gravity Interpretation and Modeling Software Based on 3D Block Models. University of Oulu, $63 \mathrm{p}$.

[35] Hjelt, S.E. (1992) Pragmatic Inversion of Geophysical Data. Springer-Verlag, Germany, 262 p. https://doi.org/10.1007/BFb0011079

\section{Submit or recommend next manuscript to SCIRP and we will provide best service for you:}

Accepting pre-submission inquiries through Email, Facebook, LinkedIn, Twitter, etc. A wide selection of journals (inclusive of 9 subjects, more than 200 journals)

Providing 24-hour high-quality service

User-friendly online submission system

Fair and swift peer-review system

Efficient typesetting and proofreading procedure

Display of the result of downloads and visits, as well as the number of cited articles

Maximum dissemination of your research work

Submit your manuscript at: http://papersubmission.scirp.org/

Or contact ijg@scirp.org 